1. 緒言

素淡電他に上って溶鋼中の酸素を知る方法については最近ますます活発となりすてに平炬や連

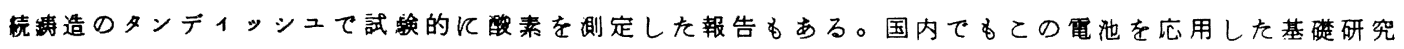

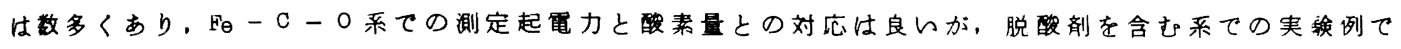
は定性的に傾向はあっても未だ定量的な扱いがなされた例は少ない。演者らはての電池の分析への応用

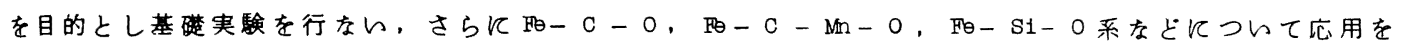
試みた。

\title{
2. 実医装置
}

固体電解質： $\mathrm{MgO}$ 管， $\mathrm{ZrO}$. $\mathrm{CaO}$ 管， $12 \phi \times 8 \phi \times 400 \mathrm{~m}$ 標準極： Pt, Rh 標準力ス：空気

鉿㑡リード：Mo 電位差計：内部抵抗 $4 \mathrm{M} \Omega$

3. 測定に及ほす諸因子の恰討

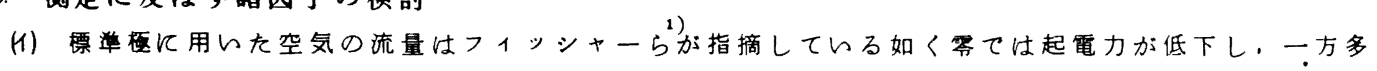
ずると両極間に熱起電力が生じて誤差の原因となるのて毎分３０００ＣＣ程度て用いた。

(口)標準極リードK PtあるいはRh，溶鋼側のリードにMoを用らるのて Pt-Mo, Rh-Mo 間の熱起電力を測定 し、後の夷験てはてれらの熱起電力を補正した。

什電位差計の内部抵抗は, 被検側の抵抗が大きいのて、充分大きいるのを用いねばならない。内部 世抗 2 M のののては不安定だが 4 M $\Omega$ ののては安定てあった。

(二固体電解質管は非常にヒートショックに弱らので容銅に浸漬する際は充分予熱する必要がある。 ヒートショックにより固体丽解質にクラックが生じると測定起電力は不安定になる。

\section{4. 測定結果}

タンマン帄で電解鉄 $1 \mathrm{~kg}$ を容解し固体電解質管を浸清した後，所定の添加郕を添加して起電力を測定 する。同時に石英管てサンプリンクして分析した睃素值と測定起龟力の対応をみた。

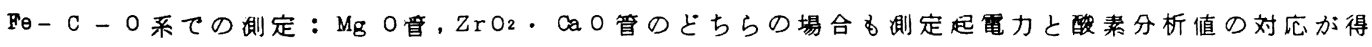
られた。

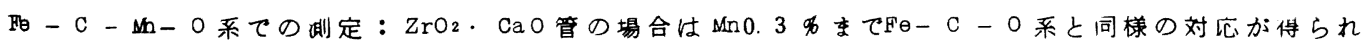

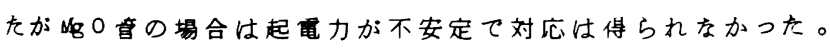

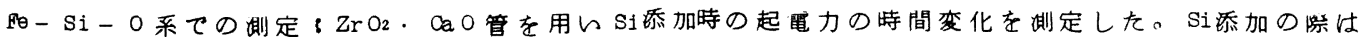

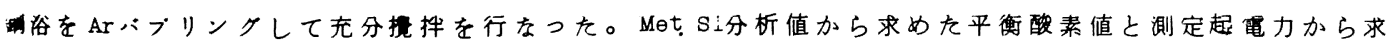

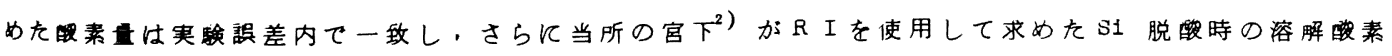
の挙和と良く一致した結果が㥂られた。
交献 1) Fischer, Archiv. Eisenhü ttenw. 36 644(1965)
2) 宮下，鉄と鋼 $52 \quad 1049$ (1966) 
（280）銅中非金属介在物の顥微鏡分析における補正法について

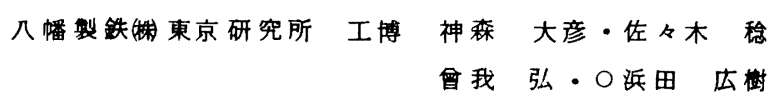

従来, 銅塊中の非金属介在物の上5に, 球状て広い粒度分布をるつるのの断面径から真の粒度分布を 推定することは試みられていないが，本研究ては，变換式を理論的に求めるととすに，実用鍽中の非金 属介在物への適用を行なった。

1. 変換式の理的的検封：ある径の球体が $x$ 軸に垂直にまったく一様に切られたときに現われる断面 半径は，図1からわかる上5に, 確事密度関としてつきの式て表わされる.

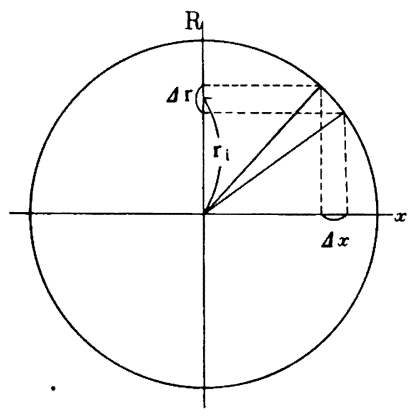

図 1 断面径の現われ方

$$
P\left(r_{1}\right) d r=\frac{1}{R} \cdot \frac{r_{1}}{\sqrt{R^{3}-r_{1}^{2}}} d r
$$

実際には半径の分布はヒストクラムで表わすのが実用的なのて，それを $\widehat{\mathrm{P}}\left(\mathrm{r}_{1}\right)$ ，ヒストクラムの巾をムとすれば

$$
\hat{\mathrm{P}}\left(\mathrm{r}_{1}\right)=\int_{\mathrm{r}_{1}-\frac{4}{2}}^{\mathrm{r}_{1}+\frac{4}{2}} \mathrm{P}\left(\mathrm{r}_{1}\right) \mathrm{dr}
$$

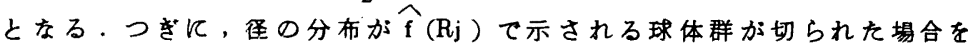
考えてみると，観測される分布 $\widehat{\mathrm{q}}(\mathrm{r})$ は，いろいろな $\mathrm{Rj}$ についての分 布の重和合せとなる。したがって，ある1つのRjに対する分布を $\hat{f}(R j)$. $\widehat{P}_{j}\left(r_{1}\right)$ て表わせば

$$
\widehat{q}\left(r_{1}\right)=\sum_{j} \widehat{f}\left(R_{j}\right) \cdot \widehat{P}_{j}\left(r_{i}\right)
$$

となる・てれを四2で考えると，ヒストクラムの

(I) から(N) 番目までに現われる分布は

(1) $\widehat{q}\left(r_{1}\right)=\widehat{f}\left(R_{1}\right) \cdot \widehat{P}_{1}\left(r_{1}\right)$

(2) $\widehat{q}\left(r_{2}\right)=\widehat{f}\left(R_{1}\right) \cdot \widehat{P}_{1}\left(r_{2}\right)+\widehat{f}\left(R_{2}\right) \cdot \widehat{P}_{2}\left(r_{2}\right)$ 以下同样にしてN番目ては

(N) $\hat{\mathrm{q}}\left(\mathrm{r}_{\mathrm{n}}\right)=\widehat{\mathrm{f}}\left(\mathrm{R}_{1}\right) \cdot \widehat{\mathrm{P}}_{1}\left(\mathrm{r}_{\mathrm{a}}\right)+\widehat{\mathrm{f}}\left(\mathrm{R}_{2}\right) \cdot \widehat{\mathrm{P}}_{3}\left(\mathrm{r}_{2}\right)+\cdots$ $\cdots+\widehat{f}\left(R_{n}\right) \cdot \hat{P}_{0}\left(r_{n}\right)$

となる。したがって，真の粒度分布はそれぞれの Rjにつんて観測される分布を果程するととによっ て求められる。

2. ガラス球による実検：250〜 $149 \mu$ の節て篩 分けたカラス球の粒径を測定して真の粒度分布を 求めておを，他方，埋込み試料てカラスの断面径 を測定して，観測される断面径の分布を上式に上 って補正した結果，両者はかなり近ら値になった。

3. 瑀中非金属介在物への適用：リムト城な らびに連鋳スラブ中の非金属介在物の組成別粒度 分布を检討した。 a）真の分布のヒストクラム ( 3 本の場合)

$$
\widehat{f}\left(R_{j}\right)=\int_{r_{i}-\frac{4 r}{2}}^{r_{i}+\frac{4 r}{2}} P\left(r_{i}\right) d r
$$




\section{（281)非金属介在物のマイクロアナライザー定量分析}

任友金属中咞理溥○白岩俊男

理博藤野允克, 村山順一郎, 渡辺雅男

1. 緒 言

鎆中の非金属介在物は組成面からみて、酸化物系 , 硫化物系, 炭・峌化物系があり、てれらの非金属介在物 組成を决定するためにマイクロアナライザー（E.P.M.A.) 加用いられている。非金属介在物の定量分析法に ついては多くの報告が出されてきた。従来より、非金属介在物の如き電導性のない物質の定量分析における

Fixed time 法と Fixed charge法の探用の可否が論ぜられ、また各種の定量補正式が適用されてきた。 本報では銅中の代表的な非金属介在物および合成或いは天然結晶を用いて、Fixed charge 法で E.P. M.A. 分析を行ない Back-scatter coefficientは Poole-Thomas ${ }^{1}$ の值を用いて補正し、吸収 補正は修正Philibert 法 ${ }^{2)}$ によ、さらに原子番号効果補正を Poole-Thomas 法によつて行なつた。1) なお、曾量吸収俰数はBirks の表 ${ }^{3)}$ によつ。との結果は满足すべきものであつた。また、Empirical correction $\left(\mathrm{Ziebold-Ogilvie)^{4 }}{ }^{4}\right.$ をも Fe-0系及びMn-Fe-S系に適用し比較した。

2. 実 酫

装は ARL一島津型を用い、加速電圧 $30 \mathrm{KV}$ ，カーボン蒸着試料を使用し Fixed charge 法にて純物質 対比によるX線強度を测定した。伹し、SKaの場合は $\mathrm{FeS}_{2}$ を対比試料に使用した。

即定した物賈は $\mathrm{TiC}, \mathrm{TiN},(\mathrm{Ti}, \mathrm{MO}) \mathrm{C}, \mathrm{ZrC}, \mathrm{ZrN},(\mathrm{Mn}, \mathrm{Fe}) \mathrm{O},(\mathrm{Mn}, \mathrm{Fe}) \mathrm{S}, \mathrm{Al}_{2} \mathrm{O}_{3}, \mathrm{SiO} \mathrm{O}_{2}$, $\mathrm{Al}-\mathrm{Ti}-\mathrm{Ca}-\mathrm{O} \cdot \mathrm{Mn}-\mathrm{Al}-\mathrm{Si}-\mathrm{O} \cdot(\mathrm{Mn} \cdot \mathrm{Fe}) \mathrm{O} \cdot \mathrm{Al}_{2} \mathrm{O}_{3} \cdot(\mathrm{Mn}, \mathrm{Fe}) \mathrm{O} \cdot(\mathrm{Cr} \cdot \mathrm{Al})_{2} \mathrm{O}_{3} \cdot \mathrm{Mn}-\mathrm{Cr}-\mathrm{Si}-\mathrm{Al}-0$ 等の銅中非金属介在物, Hematite $\left(\mathrm{Fe}_{2} \mathrm{O}_{3}\right)$, Magnenite $\left(\mathrm{Fe}_{3} \mathrm{O}_{4}\right), \operatorname{Ruby}\left(\alpha-\mathrm{Al}_{2} \mathrm{O}_{3}\right)$, Quartz $\left(\mathrm{SiO}_{2}\right)$, Pyrite $\left(\mathrm{FeS}_{2}\right)$, Copper pyrite $\left(\mathrm{CuFeS} \mathrm{F}_{2}\right)$ 天然結晶および合成非金属介在物 (Mn-SiAl一0系）中の㗉軽元素を除く全元素を定量した。

3. 定量補正

(a) Fized charge法と Fixed time法との換算は Poole-Thomas の值を用いて理論的に行なつた。 ての方法を非金属介在物の定量分析に適用し得るととは実験によつて確認している ${ }^{5}$ 。

(b) 吸収補正仙修正 Philibert 法により、二回綝返し計算によつた。

(c) 原子番号効果をPoole-Thomas 法を用いて更に行ない、それそれの元素の重量分比を求め、とれより 化学量論值を算出し、その合計について誤差を求めた。

(d) Empirical correction method Fixed charge測定值およびFixed time 換算值に対 して適用し、 $\mathrm{Fe}-0$ 系の $\mathrm{Fe} \cdot \mathrm{Mn}-\mathrm{Fe}-\mathrm{S}$ 系の $\mathrm{S}$ 等について定量値を求めた。

4. 結 果

(a) 試料面の蒸着，二次電子発生の防止が完全であれば、Fixed charge法にて問題はない。

(b) 定量補正に修正 Philibert 補正および原子番号補正を行なえば、アルえナ系を除きさ5 \%以下の誤差 にて定量補正を行ない得た。アルミナ系ではA1 が高値にでる(+10\%以下)傾向があつた。

(c) Empirical methodによる定量補正結果も実用的には良好な結果を得た。

1) D.M.Poole et al.. J.Inst.Metals. 90, 228(1961-2), 2) J.Adler et al., Proc. 4th. Conf. X-ray opt. (Paris), p.210(1966), 8) L.S.Birks, Electron

Probe Mieroanalysis (1963), 4) Ziebold et al.. Anal.Chem.. 36, 322(1964), 5) 白岩他、1968 応用物理学会秋期講演。 
（282）酸亲ガ人中の微量室素の定量

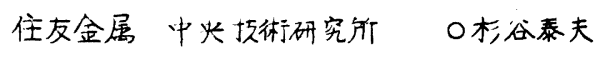

\#上俊戟

\section{1. 緒言}

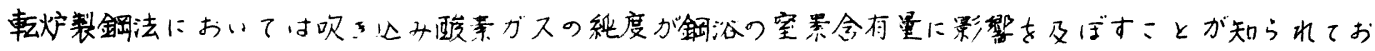
リ，一般に $99.5 \%$ 以上の高紙度のわのが使用こ扎ている。二の高級度酸素がス中に含ま水る不絍物とし

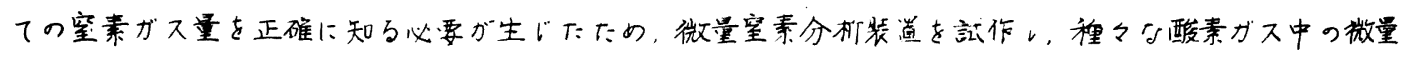
窒素の分析を行ヶった。今までにわ酸素がス中の微量空素の分析について2，3報告がるされているが

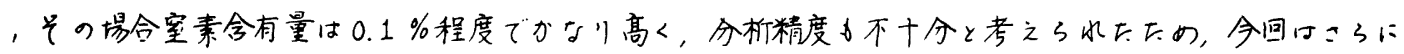

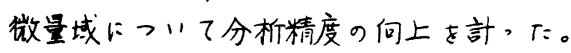

2. 分析方法夕王装置

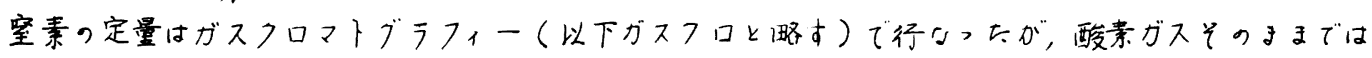

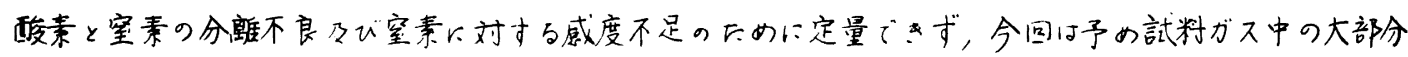

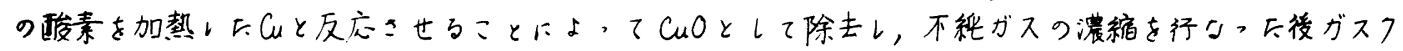

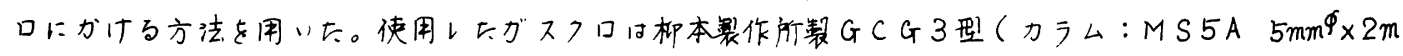

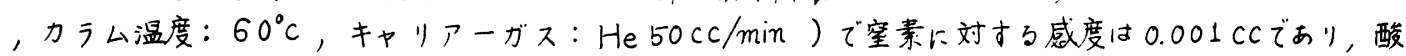
素ガス中の窒素を $0.0001 \%$ で分析するには最低500CCの試料ガスを分折にカける必要がある。今回は

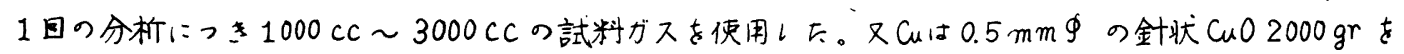
水素で遥元した。のを使用した。分析は先ず試料力゙スを封入レた瓶とCUを封入レた管とをコッフを通じ

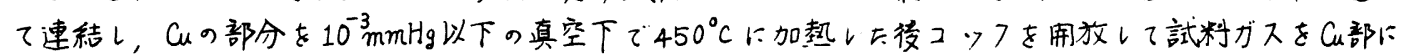

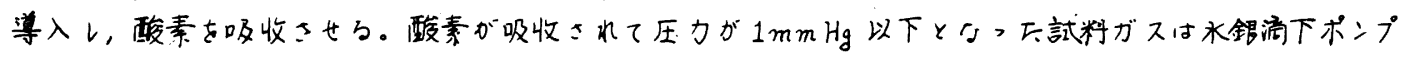
で再捕集いてガスフロに送入才る。Cuは数回の分析により酸 素の吸收能力が低下寸る下の，適时水素で遗元レて使用レ下。

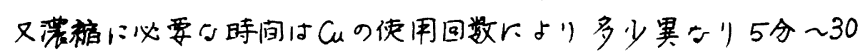

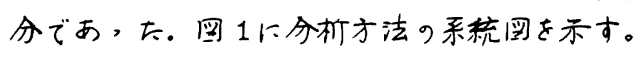

3. 分析結果

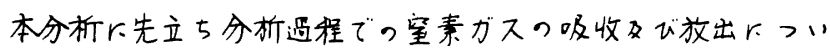
て調查レた結果、C等による空素ガスの吸收け全く考虑する必

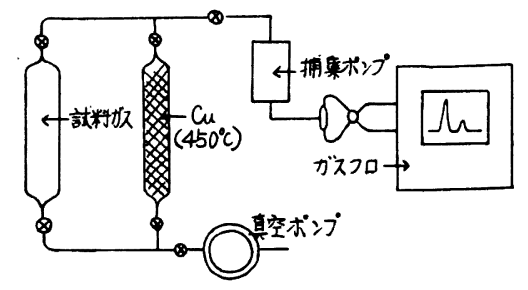

圆 1

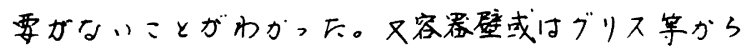
の吸蔵ガスの放出による空素ガスの增加け犲㭙间 1

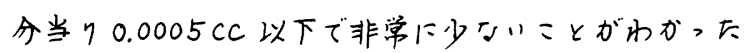
。次にボンで詰の酸素ガスについて繰这し分析レ下結 果の一例を表1示す.以上なクこのようる分析才法に より酸素がス中の窄㶳を0.001\%までは十分に分析で そることがわがた。又市販の種クのボン一゙詰の酸素 ガスを分析レ下結果，空素合有量は $0.001 \%$ ～ $0.2 \%$ の间でばらついておリ，0.01\%〜0.03\%のののが最も 多がた。

永1酸素がスの程返レ分析結果

\begin{tabular}{|c|c|c|c|c|c|}
\hline \multirow[b]{2}{*}{$\begin{array}{l}\text { 分析 } \\
\text { No }\end{array}$} & \multirow[b]{2}{*}{$\begin{array}{l}\text { 分析但 } \\
\left(N_{2} \%\right) \\
\end{array}$} & \multicolumn{2}{|c|}{ 办 析 } & \multicolumn{2}{|l|}{ 保 件 } \\
\hline & & $\begin{array}{l}\text { 言料年量 } \\
\text { (cc) }\end{array}$ & $\begin{array}{l}N_{2}+\frac{1}{1} \\
(c) \text { c) }\end{array}$ & 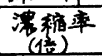 & 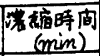 \\
\hline 1 & 0.0080 & 1732 & 0.138 & $>346$ & 26.5 \\
\hline 2 & 0.0073 & 1655 & 0.121 & $>332$ & 38.0 \\
\hline 3 & 0.0072 & 1665 & 0.120 & $>336$ & 52.0 \\
\hline 4 & 0.0074 & 1553 & 0.114 & $>311$ & 11.5 \\
\hline 5 & 0.0072 & 1584 & 0.114 & $>317$ & 17.0 \\
\hline 6 & 0.0075 & 1685 & 0.127 & $>337$ & 9.0 \\
\hline 7 & 0.0074 & 1705 & 0.126 & $>341$ & 9.5 \\
\hline 8 & 0.0080 & 1685 & 0.134 & $>337$ & 11.0 \\
\hline 9 & 0.0077 & 1687 & 0.130 & $>338$ & 9.5 \\
\hline 10 & 0.0082 & 1700 & 0.139 & $>340$ & 7.5 \\
\hline$\overline{\bar{x}}$ & 0.0076 & & & & \\
\hline
\end{tabular}




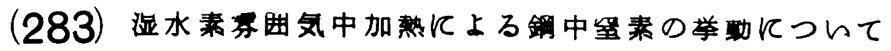

富士敇中央研究所

川村和郎工渡辺四的

○大坪至

後蔽助

1 草

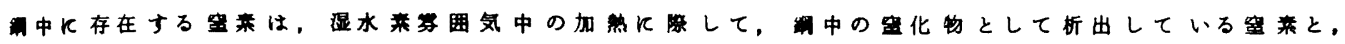

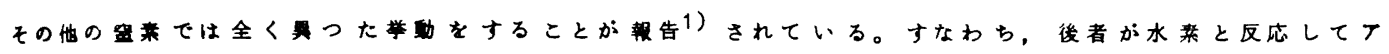

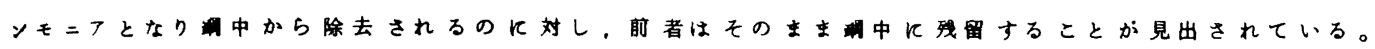

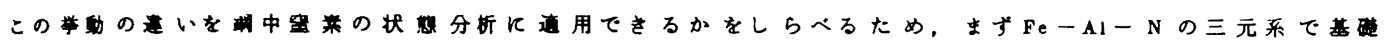
的詥をたこなった。

2 实方法

表 1 散試材

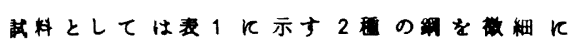
切咱したすのを用いた。鈢しし点を调節し

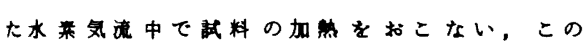

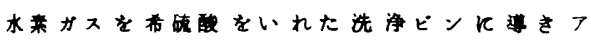

\begin{tabular}{|c|c|c|c|c|c|c|c|}
\hline 武 & \multicolumn{6}{|c|}{ 化学的組成 } & \multirow{2}{*}{ 篎処理 } \\
\hline 料 & 0 & $8 \mathrm{i}$ & $\mathbf{M n}$ & Al & $\mathbf{N}$ & $\begin{array}{l}\text { Nas } \\
\text { AIN }\end{array}$ & \\
\hline $\mathbf{A}$ & 0.005 & 0.19 & 0.58 & 0.045 & 0.028 & $<0.001$ & $\mathrm{Ar}$ 気流中 $1350^{\circ} \mathrm{O} 1 \mathrm{hr}$ 後水冷 \\
\hline 0 & 0.005 & 0.19 & 0.58 & 0.045 & 0.028 & 0.020 & 同上，Ar気流中 $750^{\circ} 01 \mathrm{hr}$ 後水冷 \\
\hline
\end{tabular}

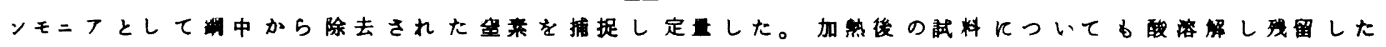

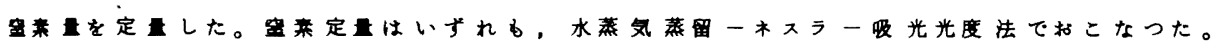

3 实蛣果扰よびその考察

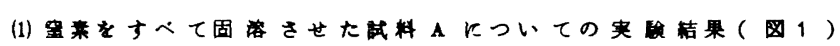
加与明らか圤上 5 K

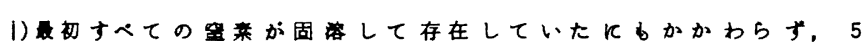

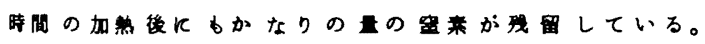

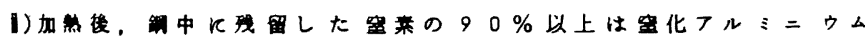
として折出している。

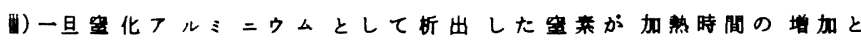

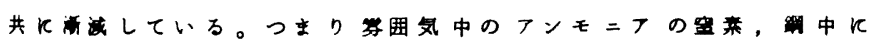

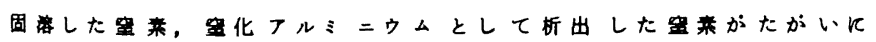

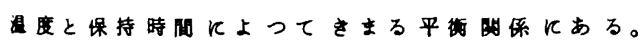

(2)息莱を化フルミニウムとして充分に析出させた試料。につ

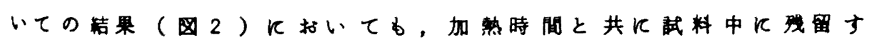

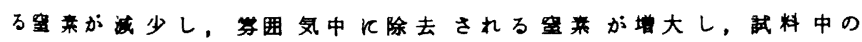

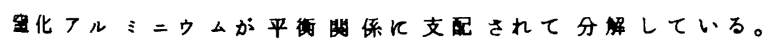

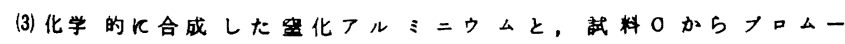

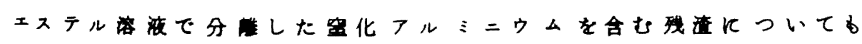

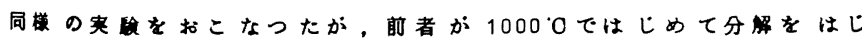
めるのに対し，後者は600 C 以下でその大部分が分解される。

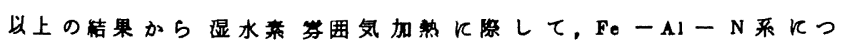

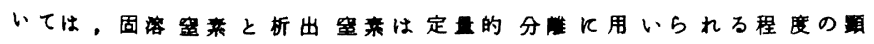
萧な萧を差をないことが明らかとなつた。

女蚮 1)V.W.Oelsen u. K.H.Sauer : Arch. Eisenhittenw.38 141-144('67)

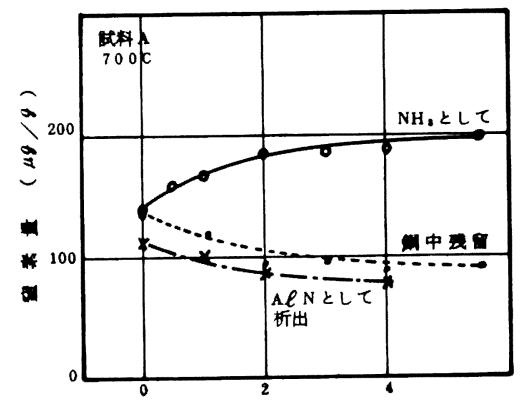

加時的 ( $\mathrm{hr}$ )

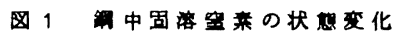

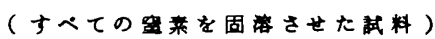

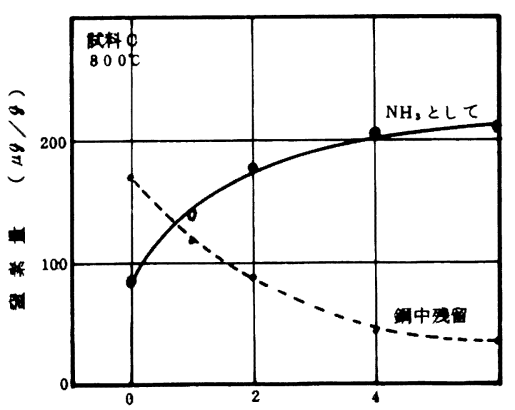

加幽時的 $(\mathrm{hr})$

因2第中析出盆萧の娍少举的 （充分にAINとして析出させた武料） 
S 284

（284）真空洛融法による钢中空美定量值におよぼ寸空素抽出速度 の効果について

\section{1. 楮 言}

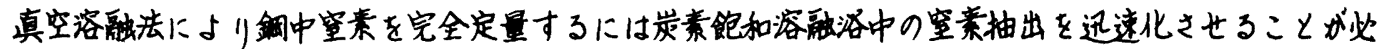

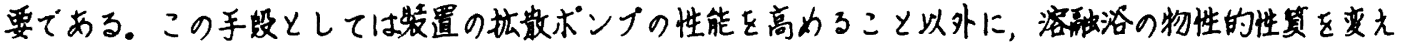

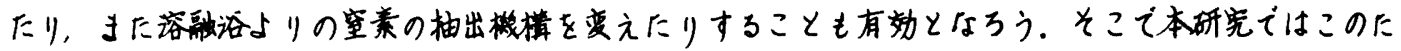
めに役立つと考えら水る諸手法を試み，空美抽出速度の促進奻果を比较するとともに勧素分析值におよ ぼ寸动果についても湌讨した。

2. 実崳才法

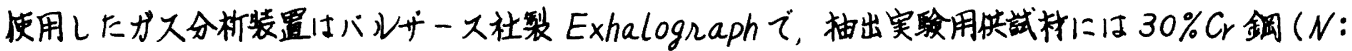

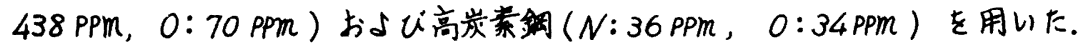

\section{3. 结果と考察}

图/に各種保件下ての溶融浴よりの空秦抽出曲線を示才 カ、窒美の最终抽出率を高为るには初期の空美抽出速度区

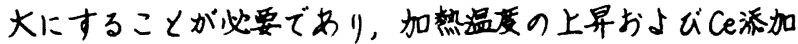

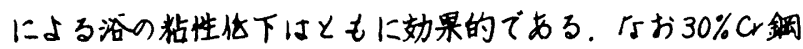

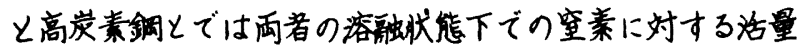

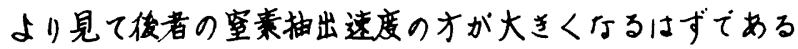
が，結果は道にあらわ水ている。この差は両者のガス含有 量の差に基因するものであつて，/種の蛠同効果によるガ 久抽出速度の捉椺が高ガス含有状管ては生ずるものと考え られる。

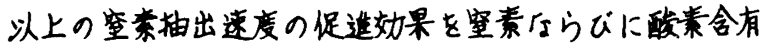
量のことなる各種試料につき速绕分析時の空素抽出华で比

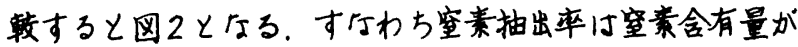
多くなるほど高くなり，Ceの同時添加はさらにこの㥀を10

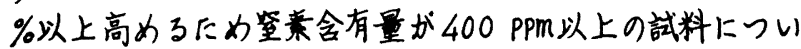
てはCeの同時添加で完全抽出が可能となる。一才同梯を勃 果け酸秦含有量についても認为的北，同に空素含有量陚料 ても政素含有量の多いものは抽出本が著しく向上し，Ceの 同时唀加を棹用才ると完全抽出も可能となる。したがつて 真空溶融法により銅中空素を定量才るに当つては浴の粘性 を任下さ世て䇪素の浴中拻放速度を早めるたけけでは不分 でつて，さらに浴から站出さ水る全ガス量を何らかの方 法て增加させて/種の满同効果による勧素の拻放抽出の促 進をけかることも必要である。

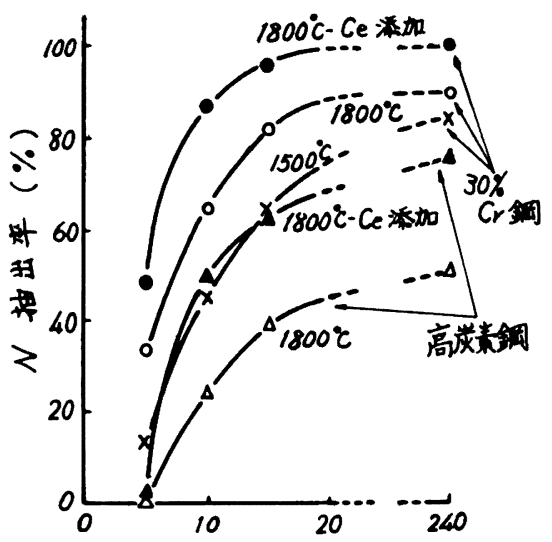

柚出洔 $(\mathrm{sec})$

因/。溶融浴力らの空素抽出速度

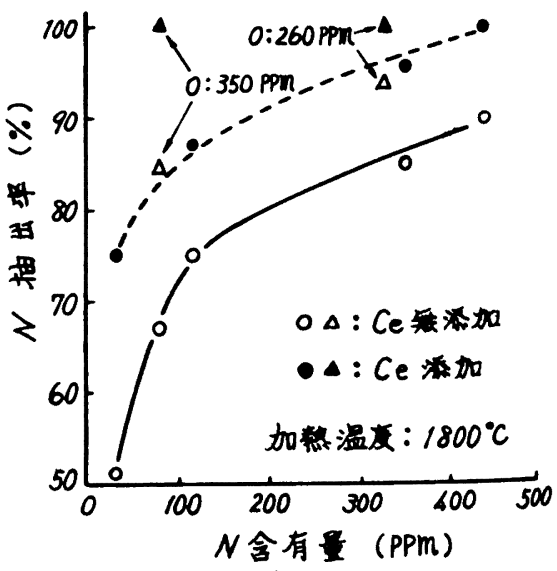

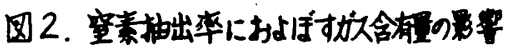


（285）酸化剂容融结による銅中の空素迅速定量法

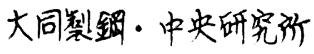

○佐層昭毫，館 要

\section{1.まえがき}

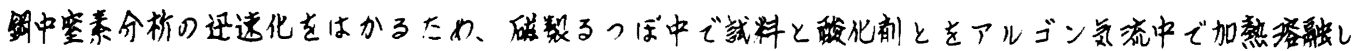

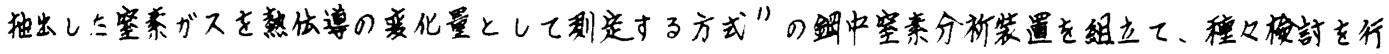

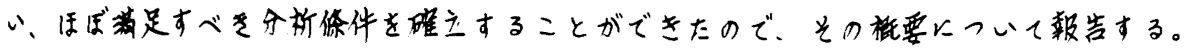

2. 装是およす゚分析方法

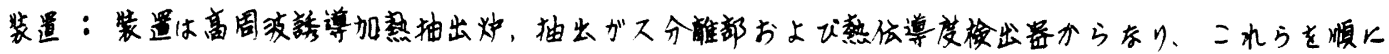
连結したものである。

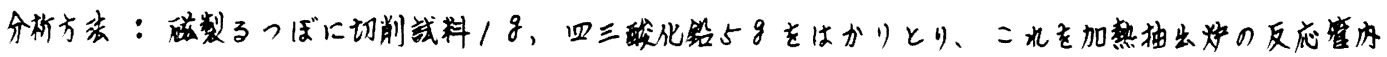

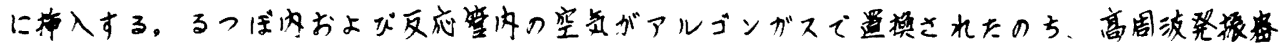

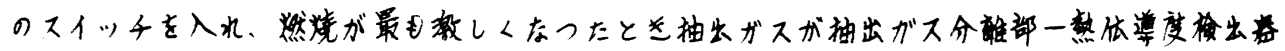

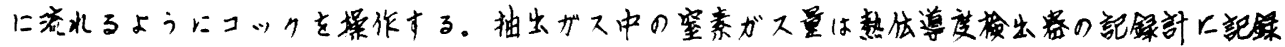

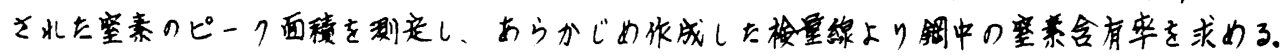

\section{3. 模钤结果}

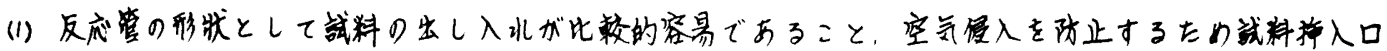

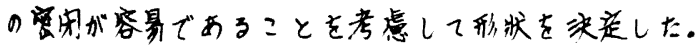

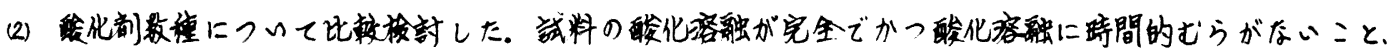

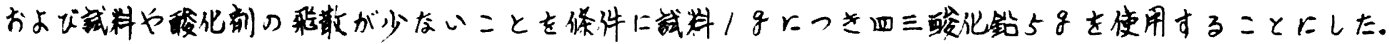

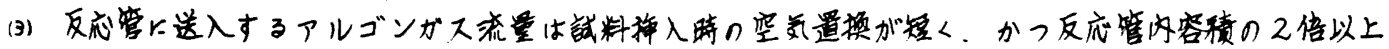

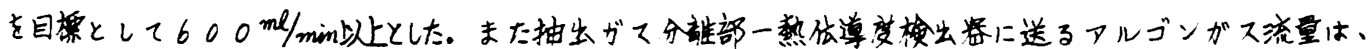

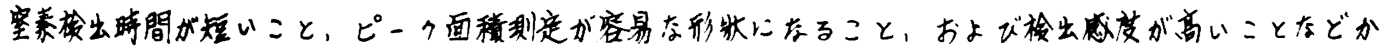
ら400 $\mathrm{ml} / \min$ そ采用することにした。

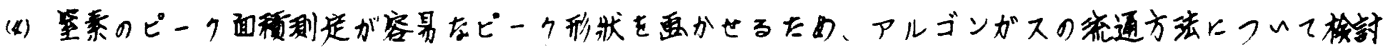

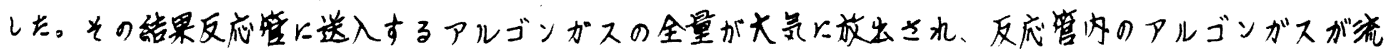

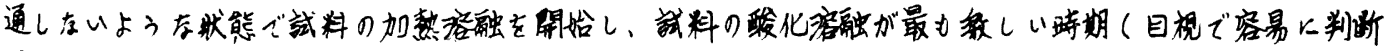

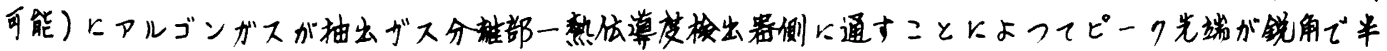
值中去で客易上面耧制定が可能なピーク形然を得ることがでさた。

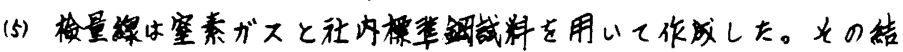

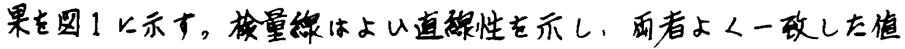
を示した。また实祭戴枓の分析を行なつたところ、本去と化学分析 佉による值とはよい一致を示した。

(6)本法の分析所要待間は○分以内であり，迅速介析法として实

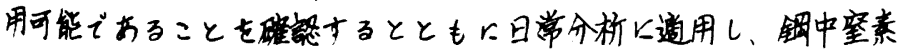
介析の能栾向上をはかることができた。

文就 1)神粦，山口：19委8578

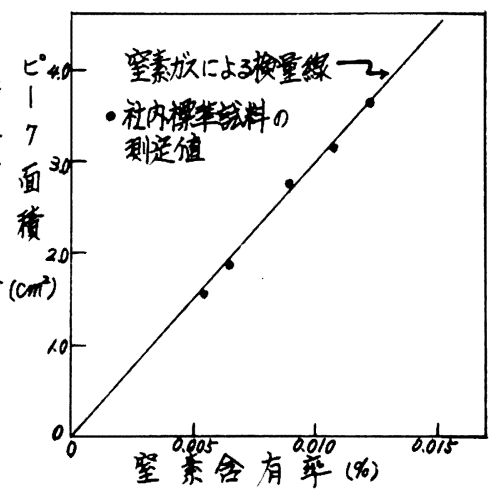

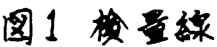


（286）発光分光・原子吸光および吸光光度法による ステンレス鋼中の全アルミニゥム定量の比较

八㬝製制東京研究所神森大彦・河島破志

田中勇・吉川建二・鵜野建夫

1. 緒 言

ステンレス鋼中の全アルミニゥム定田のため，発光分光分析酸化粉末法・原子吸光分析法お上び吸 光光度法を比較検討した，その結果，アルミノン吸光光度法ては磁気水銀陰極㫣解お上びチタンのクへ ロン分嚄に上る共存元妻除去に注意が必要てあった。

2. 分析方法

(1) 発光分光分析酸化鉄粉末法試料 $0.1 \mathrm{~g}$ を王水で溶解し，硝酸塩に变えたのち酸化㿮末試料と する.酸化鉄試料は重量比にして，3倍量の黒铅末を添加混合したすのを分光分析用試料とし，発光分 光分析用黒鉛補助電極飞つめ, 直流アーク $10 \mathrm{~A}$ て励起発光し, 分散度 $2.4 \mathrm{~A} / \mathrm{m}$ の分光器て分光し, 予 備放電なし，露光時間 45秒て富士ブロセス乾板に掫影する。分析線对は $0.001 \sim 0.01 \mathrm{Al} \%$ K対して，AI $3082 \mathrm{~A} / \mathrm{Fe} 3090 \mathrm{~A}$ を，0.01 0.1 Al\% K対して，AlI $3082 \mathrm{~A} / \mathrm{Fe} 3078 \mathrm{~A}$ 用々，乾板のr補正お上 び鉄量補正をおてない,ステンレス鈰中の全アルミニゥムを定量する。

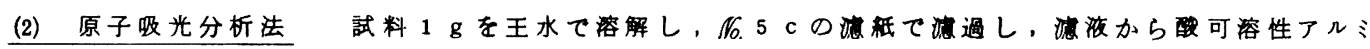

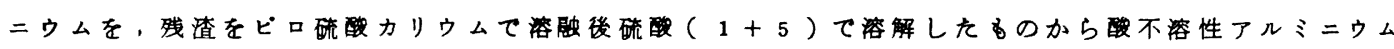
を定量し，その合量をステンレス銅中の全アルミニウムの分析値とする。試料はアセチレンー覀酸化㕵 素ガス中て然焼し，光源ランブからのAl3093Aの吸光度を測定し，0.001〜0.080 Alを定量する。

(3) アルミノン吸光光度法 JIS G 1224 ○改良法として, 試料 $1 \mathrm{~g}$ を硫酸お上び過酸化水来

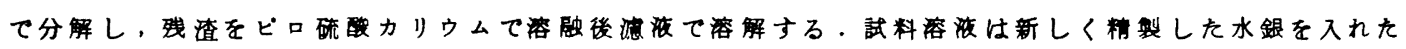
磁気水鎮陰電解畨に移し，鉄・クロム・ニッケル・銅お上びモリブテンを除去するために1〜15時間

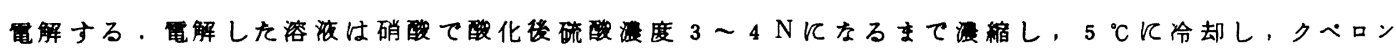

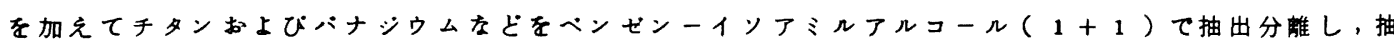
出残液は硝酸を加えてクヘロンを分解し，p-ニトロフェノールアルコールを指示来として，アンモニ

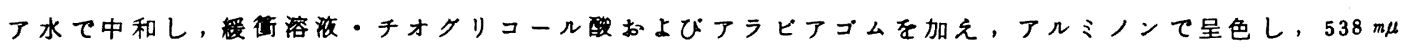
付近の吸光度を測定し，ステンレス銅中の全アルミニウムの定是をおてな5．

3. 結論

ステンレス銅中の全フルミニゥムの定量において，上記3方法を用いて分析值の比較検討をおてなっ た結果，つきのてとが明らかになった。

(1) 分析値の比較におらて，発光分光分析・原子吸光分析お上びフルミノン吸光光度分析とすにほほ 一致した值がえられた。

（2）3方法の迅速性・分析コスト・分析精度などの分析の経斉性を考虑すると，つきのてとからえる. (i) 原子吸光分析は最す良好な方法て，工場の日常作羓分析として取り入れる場合はその導入が容 易てある。

(ii) 発光分光分析は分析精度が最。良好て，試料探取量が少量てすみ，多数試料中の多種類元素を 同時飞処理でる点て良法てある。

(ii) 改訂アルミノン吸光光度法ては，迅速性，分析コストに的して樶る劣る。分析精度は分析技衡 者が修すれば，さらに向上てをると考えられる。 
鋼中カルシウムの発光分光分析法

\section{日本蹣管 技術研究所工博 井樋田睦}

\section{1. 緒 言}

最近カルシウム快削銅などカルシウムを添加した鋼種が出垷し，低湿度のカルシウムを定量する必要 が多くなった。化学分析法す分光分析法す従来の定量法ては前処理が繁雑であるのて、能率问上のため に固体試料を直接発光する分光分析法を検討した。分光分析用の標染試料かないのでず回転電極を用 らろ容液分光分析法を検討確立し，ての方法に上って標準值を决定した試料により直接分光分析する方 法を確立した。

\section{2. 実装置}

分光器: エ : 一 型平面回折格子分光写真器発光置: 島津高性能発光置 测光置：島律投影式ミクロホトメーター（ P D - 20 型 $)$

3. 回転電極を用いる溶液分光分析法

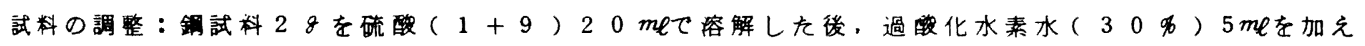

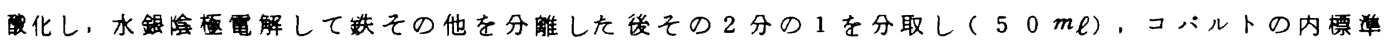
液( Co $50 \mathrm{mg} / \mathrm{m} \ell)$ を $1 \mathrm{~m} \ell$ 加え溶液試料とした。

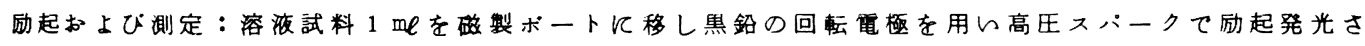
せスペクトルを掫影し、コバルトとカルシウムのスベクトル楾の強度比を測定した。使用した線対は

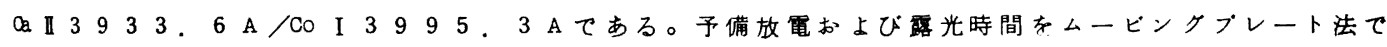
検討し、スペクトル線の強度比が安定する条件を求め, 予備放電 120 秒, 露光 30 秒と決定した。作 成した検量線加実際試料を定量し，ての試料を直接分光分析用の標準試科供した。

4. 固体試料の直接発光分光分析法

発光条件の検討：試料を空気。アルゴン，窒素，炭酸カス中で枋起し，カルシウムの検出感度と強度 比の再現性を種々の発光条件（高王スパーク，低王スパーク）で検討した。乙の結果，検出感度に対す

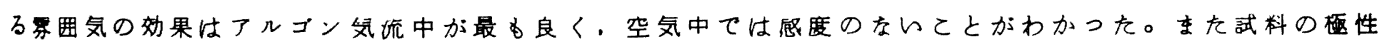
はマイナスの方が感度が良い。アルコン気流中ては高王スパーク，低王スハークとす感度は良いか，ス

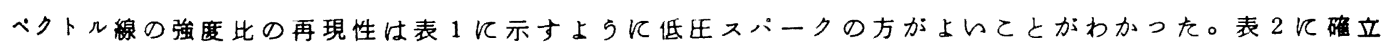

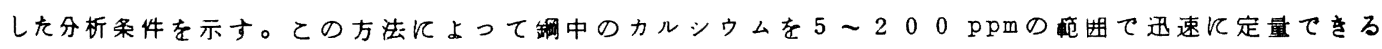
上らになった。精度は $\overline{\mathrm{X}} \div 50 \mathrm{ppm} \quad \mathrm{CV} \div 13 \%$ あるる。

表 1. 強度比の再現性

\begin{tabular}{|c|c|c|}
\hline 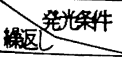 & 高印スパーク & 低任スパーク \\
\hline 1 & 1. 21 & 1.06 \\
\hline 2 & 0.84 & 1.07 \\
\hline 3 & 0.96 & 1.02 \\
\hline 4 & 0.73 & 1.07 \\
\hline 5 & 0.77 & 1.04 \\
\hline 均 & $0.90_{2}$ & 1.052 \\
\hline 㣀隼漏差 & 0.197 & 0.022 \\
\hline 変新係致(奴) & 21.8 & 2.1 \\
\hline
\end{tabular}

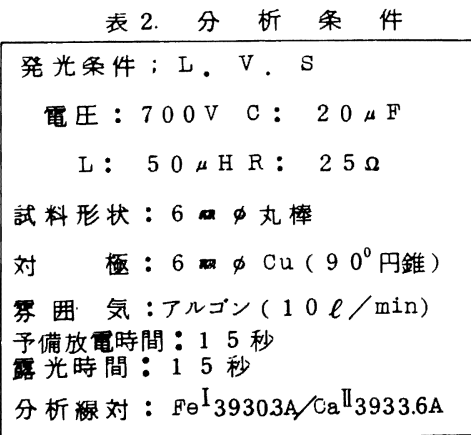


（288）吸光光度分析方法の梚量線の管理

1、緒容

特殊製金国、津金不二夫，○镰食正孝 日本铜管。寺周英喜。

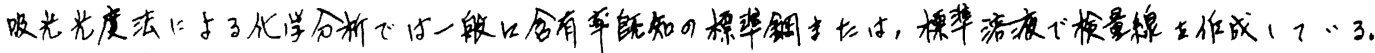

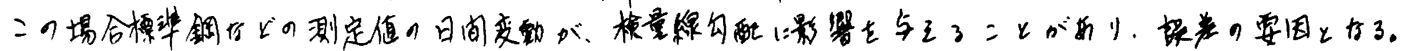

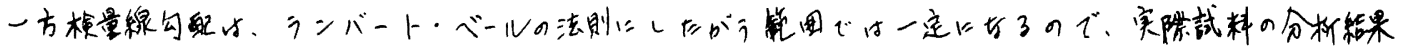

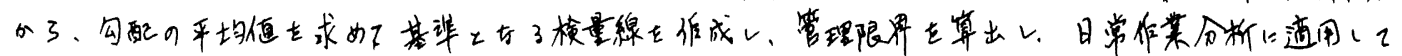
良好敀果心得了心有。

2, 基辈椣量線9倠成方法。

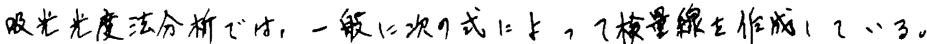

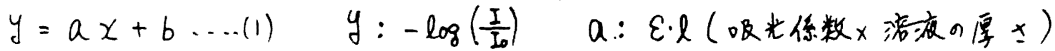

$$
\begin{aligned}
& \text { 义: 溶液度 b: ブランク值 }
\end{aligned}
$$

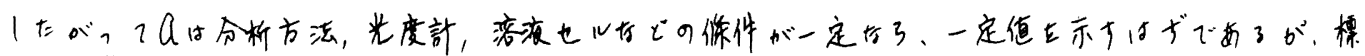

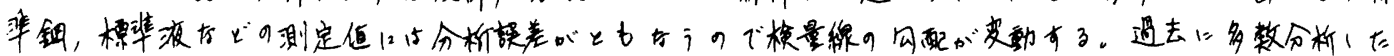

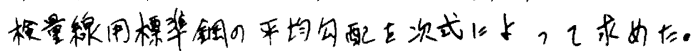

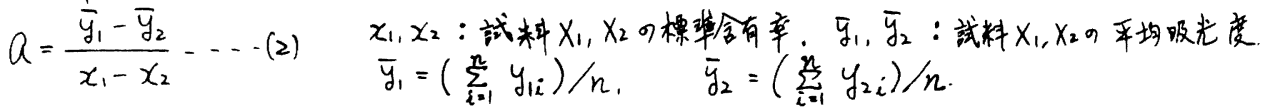

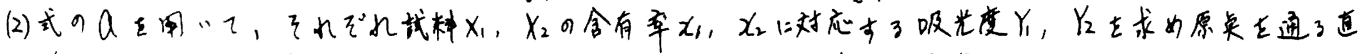

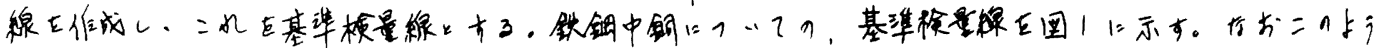

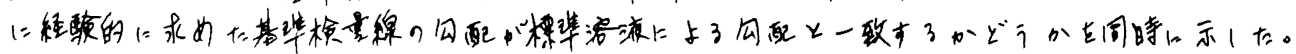
○基辈模量棌に上了含有率の算出方法。

(1)ブクンク值の決这(国1参照) $\quad y_{1}-Y_{1}=d_{1} \quad y_{2}-Y_{2}=d_{2}$

$$
\left(d_{1}+d_{2}\right) / 2=d \quad(\text { ブランクの吸光度) }
$$

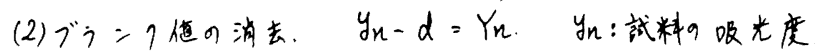

$$
\begin{gathered}
Y_{n}: \text { 試料のブラン? } \\
\text { 吸光度。 }
\end{gathered}
$$

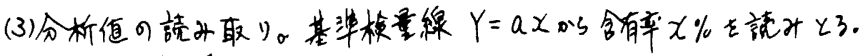

3、模量線管理, 結果

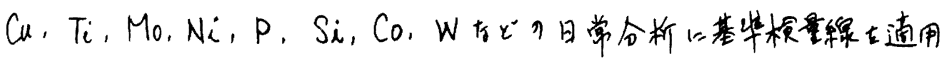
(たが例とレてWについての結果を示す。

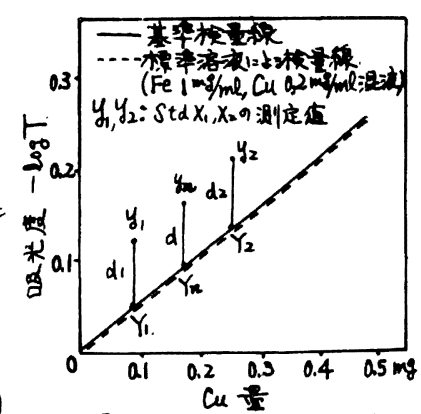

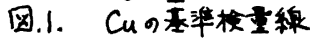
测定值の变動の平均びが過去と大き度

\begin{tabular}{|c|c|c|c|}
\hline 方 法 & 乎均值 $(\%)$ & 標㖕偏差 (\%) & 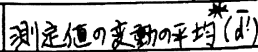 \\
\hline 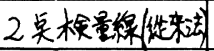 & 5.75 & 0.164 & $3.10 \quad(n=70)$ \\
\hline 其洋柃量的的法 & 5.81 & 0.039 & $3.63(n=11)$ \\
\hline
\end{tabular}

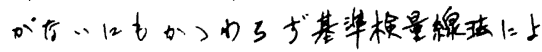
フ工管理市子と分析精度。゚向上する二と が明らかにたった。このようにして桋量 線す管理方法を改害をることによ、て、

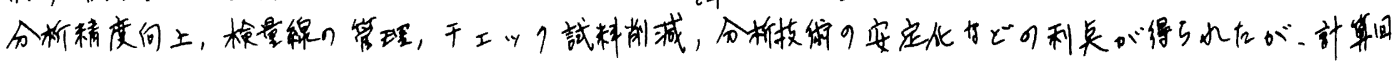

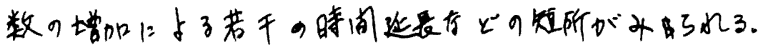


(289)

$$
\begin{aligned}
& \text { パラローズア二リン吸光光度法による } \\
& \text { 铸銑铁中检微量いか门日定量法 }
\end{aligned}
$$

神户製銅所中央研究所原宽山田二朗

○杉本公雄山口 勝岩切治久

1，绪言

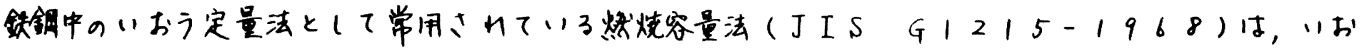
方有量0、005\%以上の試料にはか適用できない。

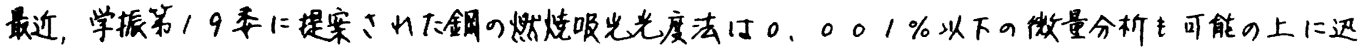

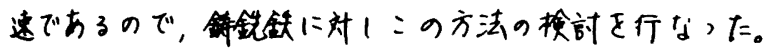

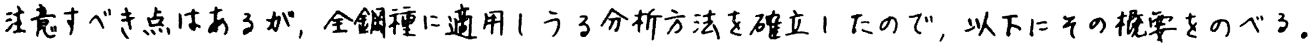

2、方法の概 田各

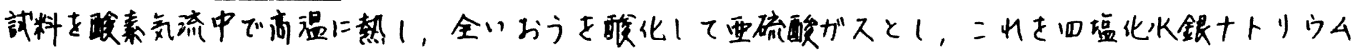

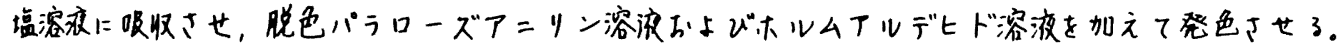

\begin{tabular}{|c|c|c|c|c|c|c|}
\hline & \multicolumn{3}{|c|}{ 然焼条 件 } & & & \\
\hline 搮作果任 & & 用 & 144 & \multicolumn{3}{|c|}{ 錻 銑 㹬 } \\
\hline 予熱 & 1 分 & $\left(\mathrm{O}_{2}\right.$ 渻量) & $0 \mathrm{ml} / \mathrm{min}$ & 4 分 & $\left(\mathrm{O}_{2}\right.$ 流量) & $0 \mathrm{ml} / \mathrm{min}$ \\
\hline 烧 & 7 分 & " & $600 \mathrm{ml} / \mathrm{min}$ & 2 分 & " & $1000 \mathrm{ml} / \mathrm{min}$ \\
\hline 追 & & 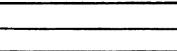 & 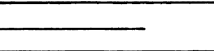 & 2 分 & $"$ & $10000 \mathrm{ml} / \mathrm{min}$ \\
\hline
\end{tabular}
$560 \mathrm{m \mu}$ 付近a吸光度を测川, “方立定量する。

3.結果9大要

1)然烧管は，每回分析する前に，ブラシを用いてよく水芜をい，内面に付着いたダストをよく除

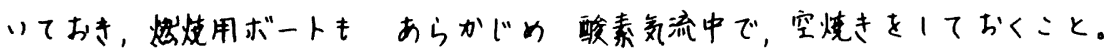

2) 試料はかりとり量は0.1 g 0.15 g以上が良好子結果が得らかる。

3) 高合金鋼に用いる助然剂とはては，五破化バナジウムがよい。

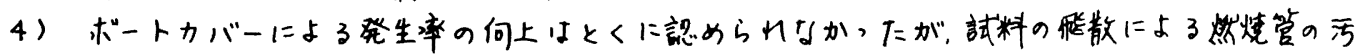
染防止にはがりの効果があった。

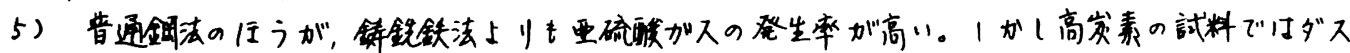

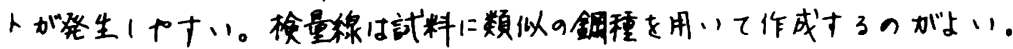

6) パラローズアニリンの脱巴に使用才る㦈酸量は10 mlがよい。

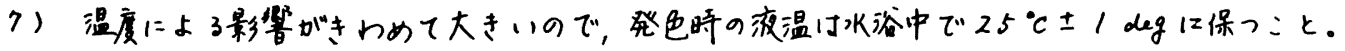

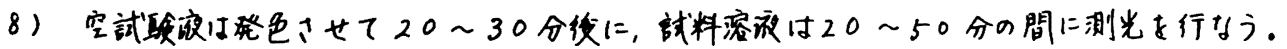

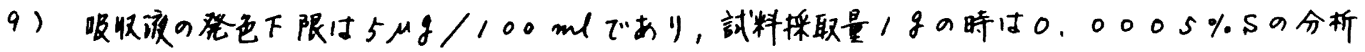
が可能でおる。なお，呈色液の分子吸光保数け40,000であった。

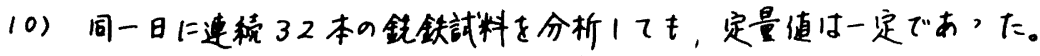

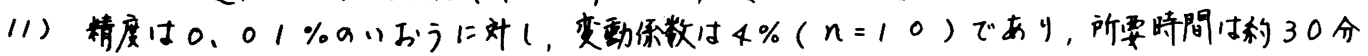
である。 
（290）䤾中臸化アルミニウム定量法につんての二三の検討

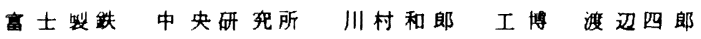

$$
\begin{aligned}
& \text { 大坪至。後藤俊助 }
\end{aligned}
$$

1 粕 言

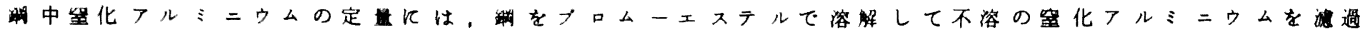

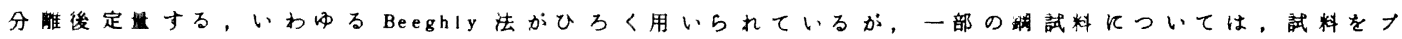

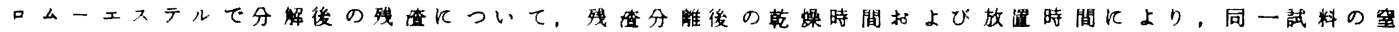
化フルミニウムの定值か著しく变助することか見出された。これについてさらに確㑇するために, 若

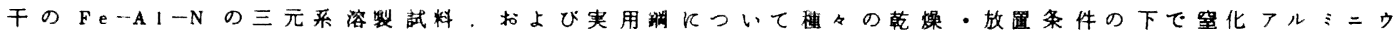
ム定値の経時变化の有無を検討した。

2 实僰置打よび条件

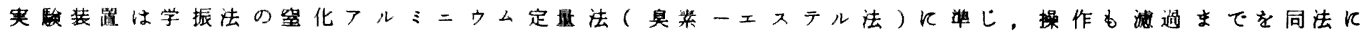

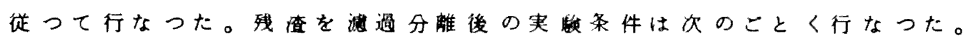

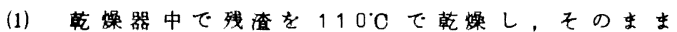

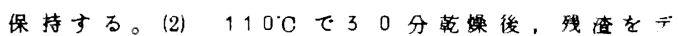
シケーター中に入れて保存する。(3) 11 吹で30 分

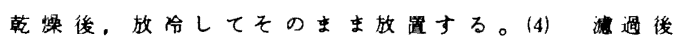
の残楂を乾蜗せずにそのままデシヶーターに保存 する。

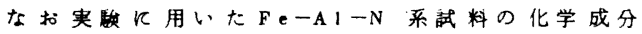
と熱処理条件を表 1 亿示す。

\section{表 1 溶製試料の組成お゙よび熱処理}

\begin{tabular}{|c|c|c|c|c|c|c|c|}
\hline 試料 & $\mathrm{c}$ & $\mathrm{Si}$ & $\mathrm{Mn}$ & Al & $N$ & $(\mathrm{~A}) \sim(\mathrm{N})$ & \\
\hline B & 0.006 & 0.19 & 0.58 & 0.044 & 0.0290 & 0.8 & $\begin{array}{r}1300 \mathrm{C} 1 \mathrm{~h} \text { 急命 } \\
7500^{\circ} 1 \mathrm{~h} \quad "\end{array}$ \\
\hline D & 0.030 & 0.018 & 0.49 & 0.080 & 0.0264 & 1.6 & $\begin{array}{l}1300 \mathrm{C} 2 \mathrm{~h} \\
1050^{\circ} \mathrm{C} 2 \mathrm{~h}\end{array}$ \\
\hline E & 0.001 & 0.005 & $<0.001$ & 0.015 & 0.0132 & 0.6 & 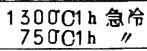 \\
\hline F & 0.002 & 0.004 & $<0.001$ & 0.042 & 0.0160 & 1.4 & 上 \\
\hline a & 0.001 & 0.004 & $<0.001$ & 0.062 & 0.0157 & 2.0 & 同 \\
\hline
\end{tabular}

\section{3 実践結果扰よび孝察}

上郡の条件下において， $\mathrm{Fe}-\mathrm{Al}-\mathrm{N}$ 系溶製試料 においては，はとんどの場合残楂を娍過分離して 48 時間後では10〜30\%低值を示した。一例を表 2 飞示す。しかし試料日と条件 4 の溥過後の残楂

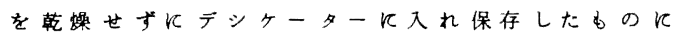
ついては，経時变化は㒛められない。また実用絧 においては，いずれの条件に扰いても壆化了ルミ

表 $2 \mathrm{Fe}-\mathrm{Al}-\mathrm{N}$ 系銅の B r エ ステル分解残渣の 窒素定量值の経時变化(实騃条件 3 )

\begin{tabular}{|c|c|c|c|}
\hline 試料 & 30 分乾蝶後 & 24 時間後 & 48 時間後 \\
\hline$B$ & $0.0210 \%$ & $0.0167 \%$ & $0.0157 \%$ \\
\hline$D$ & 0.0202 & 0.0174 & 0.0140 \\
\hline$E$ & 0.0054 & 0.0050 & 0.0047 \\
\hline$F$ & 0.0159 & 0.0142 & 0.0137 \\
\hline$G$ & 0.0149 & 0.0148 & 0.0146 \\
\hline
\end{tabular}

こウムの定是值飞経時变化は証められなかつた。

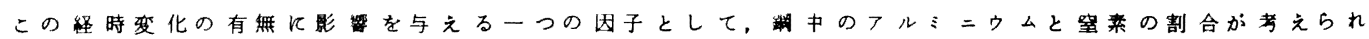

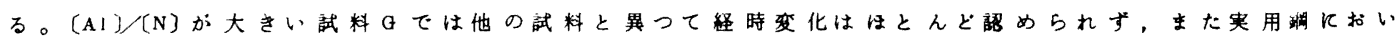

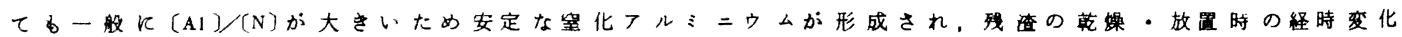

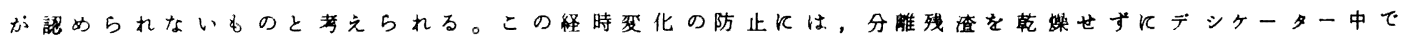

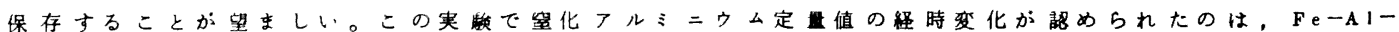

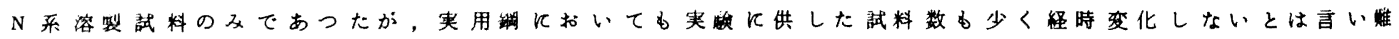
い。 
(291) 鋼 中バナジウム化合物定量

任友金属 中研 新見 敬古 ○仲山 㣚
三輪 勉

\section{耤 言}

低炭素中のバナジゥム化合物の中でV CならびにV Nの抽出に㙁酸、酸生電解液䨋解法な どが用いられている。しかしながら鋼中のバナジゥム化合物を抽出するためには，水溶液系電 解法が最す確実な方法であると考えられた。とのような観点より水溶液系電解法を中心に，抽 出方法と抽出されるバナジウム化合物との関連性ならびに，化合物の組成について検討を行な つたので，その結果について報告する。

\section{実 䤅}

(1) 供試鎆の組成と熱処理条件

実嗱に用いた供試錀の組成と熱処理条件を示す。

\begin{tabular}{|c|c|c|c|c|c|c|c|c|c|c|c|}
\hline 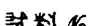 & $C$ & & $M_{n}$ & $\mathrm{~V}$ & $N$ & & 劫 & הח & 现 & 条 & 140 \\
\hline & & & & & & & & & & & \\
\hline 1 & 0.18 & 0.05 & 0.04 & 0.87 & 0.005 & $300^{\circ} \mathrm{C}$ & $\times 1 \mathrm{hrW} . \mathrm{Q}$ & $\rightarrow$ & & $0{ }^{\circ} \mathrm{C} \times$ & $0.5 \mathrm{hrW} . \mathrm{Q}$ \\
\hline 2 & 0.003 & $<0.01$ & 0.02 & 0.11 & 0.018 & & " & $\rightarrow$ & 100 & $0^{\circ} \mathrm{C} \times$ & $1 \mathrm{hrW} \cdot \mathrm{Q}$ \\
\hline 市眅釦 & 0.11 & 0.30 & 1.40 & 0.08 & 0.005 & & " & $\rightarrow$ & & $0^{\circ} \mathrm{C} \times$ & $10 \mathrm{hrW} \cdot \mathrm{Q}$ \\
\hline
\end{tabular}

(2) 抽出分離法

抽出分離法の方法間の比較検討を行なうために、水溶液系電解法( 5 タクエン酸ナトリウム十

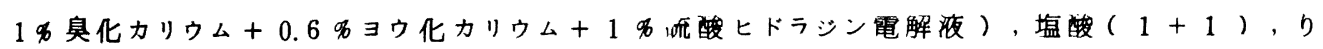

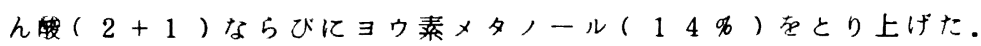

\section{実鞛秥果}

(1) 武科、1ではV C 、Na 2 ではV N が析出しており，てれらの武料については抽出法と抽出 残さの分听値との間に相荤は認められず、いつれの方法を用いてもよいととが判つた。

(2)市眅鋼については塩毁, りん酸に比較して水溶液系電解法で抽出した残さ中の $\mathrm{Fe}, \mathrm{Mn}$ はも とよりVす著しく高い值を示した，電解法の抽出残さ中の $\mathrm{Fe}$ ならびに Mn の值は，セメンタイトと㧧化物によるものである。 酸抽出法に比較して電解法の抽出残さ中のVが高值を示す理由 として，䤡中にVC 以外に $(\mathrm{FeV})_{8} \mathrm{C}$ が析出していて, ての 両者が抽出されたととによるものと考元られた。るそてで電解抽 出残さに塩酸（1+1) 加えて，七メンタイトを分解した後 の不溶生残さ分析值は酸抽出残さ中の元素分析値ともよく一致 した值を示たので，電解抽出法と酸抽出法とのバナジゥム分析 值の差は $\mathrm{V}$ as $(\mathrm{FeV})_{8} \mathrm{C}$ と見做される。

(3) バナジウム酸化物は酸抽出法では低值を示したが， ヨウ素メタノール法では確実に抽出できることがわかり 表 2 抽出方法間の比較

\begin{tabular}{|c|c|c|c|}
\hline \multirow{2}{*}{ 㹨出法 } & \multicolumn{3}{|c|}{ 残さ分析值 (\%) } \\
\hline & V & $\mathrm{Fe}$ & $\mathrm{Mn}$ \\
\hline 丽 解 法 & 0.059 & 0.90 & 0.13 \\
\hline りん酸 & 0.041 & $<0.01$ & $<0.01$ \\
\hline 塩酸 & 0.040 & $<0.01$ & $<0.01$ \\
\hline ※残さ処理 & 0.039 & $<0.01$ & $<0.01$ \\
\hline
\end{tabular}

*電解抽出残さ海酸を加えて七 メンタイトを分解後の不溶性残 さ分析值

供試鋼中のパナジウム酸化物の分析を行なつた結果では，酸化物型バナシウム分析值は 0.001 わ以下であり，酸化物の補正の必要性は認められなかつた。 
（292）鋼中硫化物の分離方法の検討

( 電解法に上る鋼中硫化物の定量法－Ｉ）

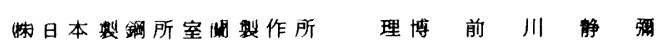

○志賀 靖 彦

I 緒言

クリンカーコッホに上る铜中の介在物、析出物の電気分解分踓法は、電解条件すな力ち電解溶液、電流路

度、容解時間、電解槽等飞㮔々の制約があるしかし硫化物のみの分離を考慮すると、それらの制約は実状

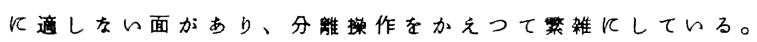

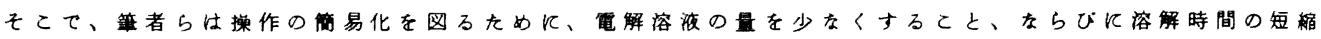
を目的にして、硫化物の電隻分解搛作を検討した。

II 検 璟

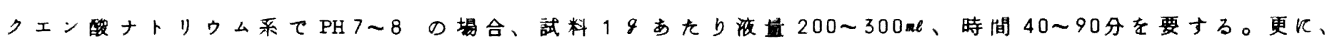

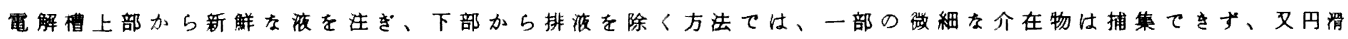

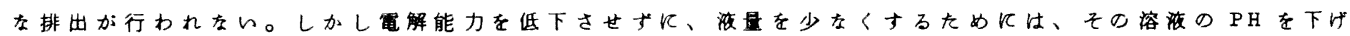
るととが必要てある。てれらの点を考属して、次の条件て検討を行つた。

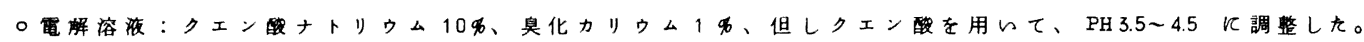
○容解時間：西流 4 5 フンベフ、電流密度 $100 \sim 70 \mathrm{~mA} / \mathrm{cd}$ 。

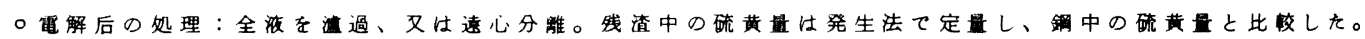

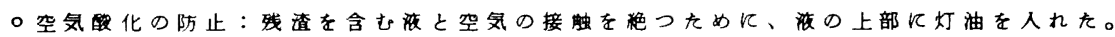

○その他：試料の硫黄量は、0.008\%。0.018\%。おび $0.025 \%$ とし、1回の溶解量は、5〜10月とした。

III 結 果

PH 3.5 と 4.5 の堨合の残渣中の硫黄量の結果を表 1 上び表 2 亿示す。上記の電解条件飞おいて、硫化物

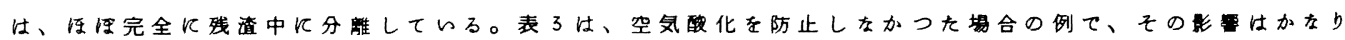
大き施

表 1 PH 4.5 の場 合

\begin{tabular}{|l|l|l|l|}
\hline$x$ & 0.008 & 0.018 & 0.025 \\
\hline 1 & 0.006 & 0.018 & 0.023 \\
\hline 2 & 0.007 & 0.017 & 0.024 \\
\hline 3 & 0.007 & 0.017 & 0.025 \\
\hline
\end{tabular}

表 2 PH 3.5 の場合

\begin{tabular}{|l|l|l|l|}
\hline$x$ & 0.008 & 0.018 & 0.025 \\
\hline 1 & 0.006 & 0.016 & 0.023 \\
\hline 2 & 0.006 & 0.016 & 0.025 \\
\hline 3 & 0.007 & 0.018 & 0.025 \\
\hline
\end{tabular}

表 3 PH 4.5 の场合

\begin{tabular}{|l|l|l|l|}
\hline$\not x$ & 0.008 & 0.018 & 0.025 \\
\hline 1 & 0.003 & 0.010 & 0.009 \\
\hline 2 & 0.003 & 0.006 & 0.014 \\
\hline 3 & 0.003 & 0.007 & 0.008 \\
\hline
\end{tabular}


（293）電解残渣の処理法の検討

(電解法による䤱中硫化物の定量法一 II )

日本㱔鈳所室制所

$$
\begin{gathered}
\text { 理博前川静解 } \\
\text { 。志贺靖彦 }
\end{gathered}
$$

I 楮 音

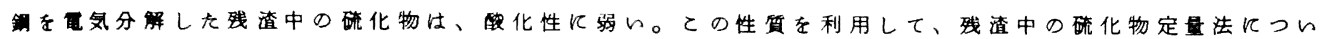
て模即した。

II 模 讨

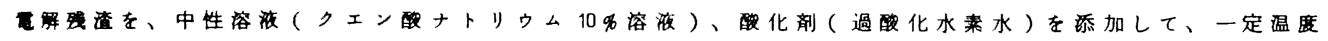
て一定時間放置后、過を行い、その沮液中の元素を定量して硫化物量を求めた。

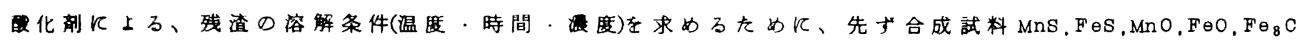
にっレてその溶解率を調へた。その結果、最適条件として中性溶液 $10 \mathrm{CC}, 5$ \%過酸化水素水 $10 \mathrm{CC}$, 温度 $25 \mathrm{C}$ ， 時間 120 分を得た。

結果

C $0.11 \%$, Mn $1.20 \%$, Si $0.20 \%$, S $0.006 \sim 0.081 \%$

の6種颣を溶製、金型に鋳込み供試材とした。

本試料の球渣について過酸化水素水処理前、 后のX線回折結果の一例を図1 亿示す。処理 前に存在していた MnS 、過酸化水妻水処理 に上り容解する。FeS は X線感度か弱にため 几、現出しなかつた。

この供試材の定量結果を表 1 亿示す。 MnS につレては、試料中の硫黄塂との関連か、か 古り明確てあるが FeS は相関性が琵められす、 とれは合成試料の場合と一致している。

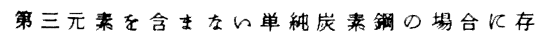

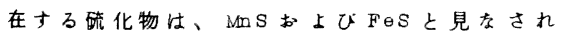
るのて、全硫黄分加 $\mathrm{MnS}$ 分の硫黄量を減し た量をF日大する方が罗当てある。
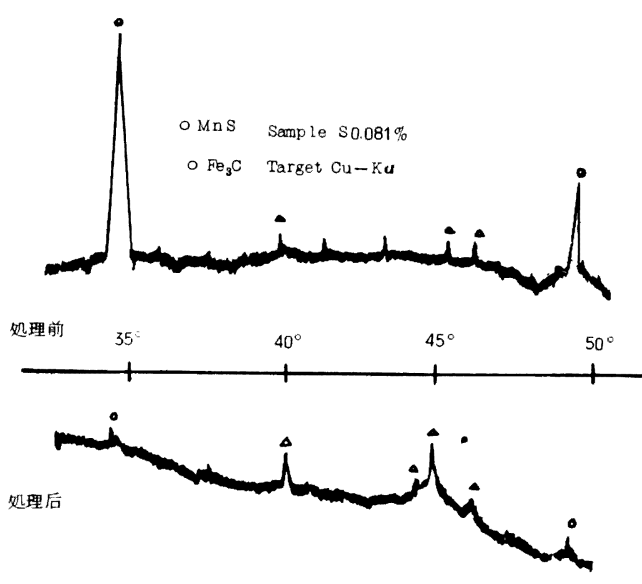

四1残渣のX線回析結果

表! MnS.FeSの定量値

\begin{tabular}{|l|l|l|l|l|}
\hline Sक & \multicolumn{2}{|c|}{$M n S P$} & \multicolumn{2}{|c|}{$F \in S \mathscr{B}$} \\
\hline 0.006 & 0.013 & 0.009 & 0.006 & 0.011 \\
\hline 0.021 & 0.023 & 0.027 & 0.006 & 0.017 \\
\hline 0.035 & 0.043 & 0.048 & 0.035 & 0.018 \\
\hline 0.051 & 0.066 & 0.068 & 0.021 & 0.017 \\
\hline 0.072 & 0.098 & 0.081 & 0.012 & 0.018 \\
\hline 0.081 & 0.114 & 0.111 & 0.011 & 0.017 \\
\hline
\end{tabular}

